\title{
A new genus and two new species of lecanicephalidean tapeworms from the striped panray, Zanobatus schoenleinii (Rhinopristiformes: Zanobatidae), off Senegal
}

\author{
Kirsten Jensen ${ }^{1}$, Kendra R. Mojica ${ }^{1,2}$ and Janine N. Caira ${ }^{2}$ \\ ${ }^{1}$ Department of Ecology and Evolutionary Biology, and the Biodiversity Institute, University of Kansas, Lawrence, Kansas, USA; \\ ${ }^{2}$ Department of Ecology and Evolutionary Biology, University of Connecticut, Storrs, Connecticut, USA
}

\begin{abstract}
Recognised for their diversity in apical structure morphology, members of the cestode order Lecanicephalidea Wardle et McLeod, 1952 known to date exhibit relatively mundane and uniform acetabular morphology. A new lecanicephalidean genus, Zanobatocestus gen. n., is proposed for two new species found parasitising the spiral intestine of the striped panray, Zanobatus schoenleinii (Müller et Henle), off Senegal that are highly unusual in acetabular morphology. Unlike the members of the 21 recognised lecanicephalidean genera, which possess simple, uniloculate suckers or bothridia, Zanobatocestus minor sp. n. and Z. major sp. n. possess biloculate bothridia. The form of their apical structures and cocoons readily distinguish the two new species from one another. Zanobatocestus minor sp. n. exhibits an apical modification of the scolex proper that is narrow and elongated, an apical organ that is small and internal, and eggs in cocoons forming linear strands, whereas Z. major sp. n. exhibits an apical modification of the scolex proper that is wide and short, an apical organ that is extensive and primarily external, and eggs in cocoons primarily as doublets with bipolar filaments. Given the typically high host specificity of lecanicephalidean cestodes, as parasites of the only genus and species currently considered valid in the family Zanobatidae, Zanobatocestus gen. $\mathrm{n}$. is likely to remain one of the less specious lecanicephalidean genera.
\end{abstract}

Keywords: Cestoda, biloculate suckers, SEM, Africa, Lecanicephalidea

Zanobatus schoenleinii (Müller et Henle), endemic to the waters of the eastern tropical Atlantic Ocean from Morocco to the Gulf of Guinea (Diatta et al. 2013), is one of the more unique batoid taxa. Historically classified as the sole valid member of the family Zanobatidae (e.g. Nelson 2006), its phylogenetic position among batoids remains unresolved (e.g. Aschliman et al. 2012a,b, Naylor et al. 2012a). While Compagno (2005) and Naylor et al. (2012b) listed as many as three species in Zanobatus, only $Z$. schoenleinii is currently considered to be valid. To date, the rhinebothriidean Rhinebothrium cadenati Euzet, 1954 (referred to as New genus 3 cadenati in Healy et al. 2009 and Caira et al. 2014) is the only tapeworm species reported from $Z$. schoenleinii.

Much recent work documenting lecanicephalidean diversity has focused at the generic level and has resulted in the erection of seven new genera (Jensen et al. 2011, Koch et al. 2012, Cielocha and Jensen 2013, Cielocha et al. 2014, Jensen and Russell 2014) within the past four years alone. Yet other genera have been resurrected (e.g. Cielocha and Jensen 2011). In combination, this work has revealed startling scolex diversity within the order, particularly with respect to the morphologies of the apical structure. In contrast, lecanicephalidean acetabular morphology is relatively conserved, consisting entirely of simple suckers or bothridia (Jensen 2005).

As a consequence, the discovery of lecanicephalideans bearing bothridia divided by a horizontal septum, among the tapeworms collected from $Z$. schoenleinii off Senegal between 2002 and 2005, was unexpected. The existence of what appear to be two distinct species exhibiting this unusual biloculate morphology was even more surprising. A new genus is erected herein for these lecanicephalideans possessing this unique bothridial form.

\section{MATERIALS AND METHODS}

Twenty-two specimens of Zanobatus schoenleinii from coastal Senegal, ranging in disk width from 19.5-34 cm, collected by spear fishing, netting or trawling were examined: two females (SE-28 and SE-29, respectively) collected off Ouakam $\left(14^{\circ} 43^{\prime} \mathrm{N} ; 17^{\circ} 29^{\prime} \mathrm{W}\right)$ on 9 January 2002 ; four females (SE-47, SE-58, SE-105 and SE-204, respectively), four males (SE-57, SE-173, SE-199 and SE-202, respectively), and three specimens of unidentified sex (SE-174, SE-200 and SE-201, respectively) collected off Soumbedioune $\left(14^{\circ} 40^{\prime} \mathrm{N} ; 17^{\circ} 27^{\prime} \mathrm{W}\right)$ on 15 January 2003; one female (SE-124) collected off Mbour $\left(14^{\circ} 42^{\prime} \mathrm{N}\right.$; $16^{\circ} 59^{\prime} \mathrm{W}$ ) on 16 January 2003; one male (SE-242) collected off 
Dijifere $\left(13^{\circ} 55^{\prime} \mathrm{N} ; 16^{\circ} 45^{\prime} \mathrm{W}\right)$ on 11 January 2004 ; two males (SE-265 and SE-294, respectively) and one specimen of unidentified sex (SE-296) collected off Kafountine, Casamance $\left(12^{\circ} 55^{\prime} \mathrm{N} ; 16^{\circ} 45^{\prime} \mathrm{W}\right)$ on 14 January 2005 ; and one female (SE$300)$ and three males (SE-299, SE-301 and SE-303, respectively) collected off Joal $\left(14^{\circ} 10^{\prime} \mathrm{N} ; 16^{\circ} 51^{\prime} \mathrm{W}\right)$ on 16 January 2005. Additional information, and for most specimens also photographs, are available in the Elasmobranch Specimen database of the Global Cestode Database (see elasmobranchs.tapewormdb. uconn.edu). These data can be accessed using host specimen Collection Codes and Numbers (e.g. SE-28).

In the field, the body cavity of each host specimen was opened and the spiral intestine was removed. Each spiral intestine was opened with a longitudinal incision. Cestodes encountered were immediately removed and fixed in vials in $10 \%$ formalin buffered with seawater and later transferred to $70 \%$ ethanol for storage, or in $95 \%$ ethanol for future molecular work. The spiral intestines and their contents were fixed in $10 \%$ formalin buffered with seawater and later transferred to $70 \%$ ethanol for storage. A piece of liver tissue from each individual was preserved in $95 \%$ ethanol for later confirmation of host species identification. The identification of eight host specimens was confirmed by Naylor et al. (2012b). Elasmobranch classification and taxonomy follow Naylor et al. (2012a,b), respectively.

At the University of Kansas, the spiral intestines were examined for cestodes. Lecanicephalidean specimens prepared as whole mounts were hydrated in distilled water, stained with Delafield's hematoxylin, differentiated in tap water, destained in $70 \%$ acid ethanol, alkalinised in $70 \%$ basic ethanol, dehydrated in a graded ethanol series, then cleared in methyl salicylate and mounted in Canada balsam on glass slides. Whole worms and scoleces prepared for scanning electron microscopy (SEM) were hydrated in a graded ethanol series, post-fixed in $1 \%$ osmium tetroxide overnight, washed in distilled water, dehydrated in a graded ethanol series, transferred to hexamethyldisilizane (HMDS) for $20 \mathrm{~min}$, air-dried and mounted on aluminium stubs on double-sided adhesive carbon tape. Specimens were sputter coated with $\mathrm{ca} 300 \AA$ of gold and examined with a Zeiss LEO 1550 field emission scanning electron microscope at the Microscopy and Analytical Imaging Laboratory, University of Kansas, Lawrence, Kansas, USA.

Selected proglottids prepared as histological sections were dehydrated in a graded ethanol series, cleared in xylene and embedded in paraffin wax according to conventional techniques. Serial sections were cut at $7 \mu \mathrm{m}$ intervals using a TBS OLYMPUS CUT 4060 microtome, attached to glass slides by floating sections on $3 \%$ sodium silicate solution and air-drying. Sections were subsequently stained with Delafield's hematoxylin, counterstained with eosin, differentiated in Scott's solution, dehydrated in a graded ethanol series, cleared in xylene and mounted in Canada balsam. Gravid free proglottids of both species were cleared in lactophenol for $\sim 30 \mathrm{~min}$ and teased apart using needles to allow examination of cocoons.

Line drawings were made using a drawing tube attached to a Zeiss Axioskop 2 Plus. Light microscopy images of whole mounts, histological sections and cocoons were taken using a Leica FireCam DFC 320 of DFC 480 and a scale bar was added in ImageJ $1.36 \mathrm{~b}$. Measurements were taken using a computer video imaging system using a Leica Firecam DFC 320 digital camera mounted on a Zeiss Axioscop 2 Plus and the image analysis program Openlab Demo Version 4.0.4. Reproductive or- gans were measured in mature attached proglottids only. Measurements are given in micrometers $(\mu \mathrm{m})$, and are provided as the range followed in parentheses by the mean, standard deviation, number of worms examined and the total number of measurements if more than one measurement was taken per worm. Microthrix terminology follows Chervy (2009). Shape terminology for scolex features and eggs follows Clopton (2004).

Museum abbreviations used are as follows: Institute of Parasitology, Academy of Sciences of the Czech Republic (IPCAS), České Budějovice, Czech Republic; Lawrence R. Penner Parasitology Collection (LRP), University of Connecticut, Storrs, Connecticut; Muséum National d'Histoire Naturelle (MNHN), Paris, France; National Museum of Natural History (USNM), Smithsonian Institution, Washington, D.C., USA.

\section{RESULTS}

\section{Zanobatocestus gen. n.}

Diagnosis. Worms euapolytic. Scolex bearing 4 acetabula, apical modification of scolex proper and apical organ. Acetabula in form of bothridia, divided by horizontal septum into 2 loculi; anterior loculus smaller than posterior loculus. Apical modification variable in form, bearing apical organ, invaginable in some. Apical organ variable in form, internal or external, primarily glandular, may be muscular, retractable into apical modification of scolex proper in some, non-invaginable. Cephalic peduncle absent. Proglottids craspedote. Longitudinal muscle bundles absent. Testes medial, arranged in 1 irregular column anterior to ovary. Vas deferens sublateral in position, extending from posterior of ovary to cirrus sac, not expanded to form external seminal vesicle. Internal seminal vesicle absent. Cirrus sac pyriform, small. Cirrus likely unarmed. Ovary compact to broadly lobate, $\mathrm{H}$-shaped in frontal view, tetralobed in cross-section. Vagina sinuous, sublateral in position, opening into genital atrium posterior to cirrus sac; vaginal sphincter absent. Genital pores lateral, irregularly alternating. Vitellarium follicular; follicles arranged in 2-3 columns on each lateral margin of proglottid, extending from near posterior margin of proglottid stopping short of anterior limit of testicular field, uninterrupted by ovary. Excretory ducts in 2 pairs. Uterus medial, saccate; uterine duct entering uterus at level of cirrus sac. Eggs in cocoons. Parasites of Zanobatus schoenleinii (Rhinopristiformes: Zanobatidae), eastern Atlantic Ocean.

Type species: Zanobatocestus minor sp. n. Additional species: Zanobatocestus major sp. n.

Etymology: The genus (masculine) is named for its type and only known host (Zanobatus Garman); cestus (in Latin), worm.

Remarks. Its unusually biloculated bothridia readily distinguishes Zanobatocestus gen. n. from the 21 valid lecanicephalidean genera (see Cielocha et al. 2014), all of which exhibit acetabula that, regardless of whether they are in the form of suckers or bothridia, are uniloculate. 
Given that the new genus is known only from Zanobatus schoenleinii, which is the only valid member of the family Zanobatidae, and the typically high degree of host specificity exhibited by lecanicephalidean genera (see Jensen 2005), it is likely that Zanobatocestus gen. n. will remain among the least speciose lecanicephalidean genera.

\section{Zanobatocestus minor sp. $\mathrm{n}$.}

Figs. $1 \mathrm{~A}-\mathrm{C}, 2,4 \mathrm{~A}, \mathrm{~B}$

Description (based on 14 whole mounts of mature worms, 8 detached proglottids, lactophenol egg preparations of 2 gravid proglottids and 4 whole worms prepared for SEM). Mature worms 963-1 635 (1 294 \pm 248 ; 13) long, maximum width at level of scolex, euapolytic; proglottids $15-22(18 \pm 2 ; 13)$ in number. Scolex 149-218 (183 \pm 26 ; 12) long by $100-170(142 \pm 19 ; 12)$ wide, consisting of 4 acetabula, apical modification of scolex proper and apical organ. Acetabula bothridiate in form, 144-216 (178 \pm 25 ; $12 ; 23)$ long by $49-95(76 \pm 10 ; 14 ; 27)$ wide, biloculated; anterior loculus broadly ovoid, $41-72(57 \pm 9 ; 11 ; 22)$ long by $42-69(57 \pm 7 ; 12 ; 24)$ wide; posterior loculus obovoid, weakly notched posteriorly, $100-162(133 \pm 20 ; 12 ; 23)$ long by $61-95(78 \pm 10 ; 13 ; 25)$ wide; ratio of anterior loculus length to posterior loculus length $0.35-0.57: 1$ $(0.44: 1 \pm 0.05 ; 11 ; 21)$. Apical modification of scolex proper narrow, elongate, invaginable, with pore-like aperture at centre, housing apical organ. Apical organ small, internal, primarily glandular, deeply to very deeply ovoid to obovoid, $38-60(49 \pm 8 ; 12)$ long by $25-34(30 \pm 3$; 12) wide.

Scolex proper covered with capilliform filitriches (Fig. 2J). Apical modification of scolex proper covered with acicular to capilliform filitriches (Fig. 2C-E) and 2 bands of hastate spinitriches (Fig. 2B,D,E). Distal bothridial surfaces covered with sparse, short gladiate spinitriches and papilliform to acicular filitriches (Fig. 2F,G). Proximal bothridial surfaces covered with acicular to capilliform filitriches (Fig. 2H,I), and sparse, short gladiate spinitriches posteriorly (Fig. 2I), denser, longer gladiate spinitriches laterally (Fig. 2H). Proglottids covered with capilliform filitriches throughout (Fig. 2L), with small coniform spinitriches anteriorly (Fig. 2K) and small scolopate spinitriches along posterior proglottid margin (Fig. 2M).

Cephalic peduncle absent. Proglottids craspedote, nonlaciniate. Immature proglottids $14-21(17 \pm 2 ; 13)$ in number, initially wider than long, becoming square, and then longer than wide with maturity; posterior-most immature proglottid $145-299(218 \pm 46 ; 14)$ long by $85-198$ $(129 \pm 35 ; 14)$ wide. Mature proglottids 1 in number; terminal mature proglottids $291-578(435 \pm 72 ; 14)$ long by 98-226 (149 $\pm 39 ; 14)$ wide; detached mature proglottids $583-1227(811 \pm 231 ; 6)$ long by $230-342(257 \pm 43 ; 6)$ wide. Testes $8-10(9 \pm 1 ; 21)$ in number, 22-66 (37 \pm 9 ; 13 ; 39) long by $40-120(77 \pm 20 ; 13 ; 39)$ wide, in 1 column essentially anterior to ovary. Vas deferens weakly sinuous, extending sublaterally from level of ootype region to anterior margin of cirrus sac, not expanded to form external seminal vesicle. Internal seminal vesicle not observed. Cirrus sac pyriform, 30-63 (42 $\pm 9 ; 12)$ long by $20-37(28 \pm 6 ; 12)$ wide, containing coiled cirrus. Cirrus likely unarmed.

Ovary compact to broadly lobate, H-shaped in frontal view, tetralobed in cross-section, 42-98 (59 \pm 15 ; 12) long by $37-113(61 \pm 21 ; 12)$ wide. Mehlis' gland posterior to ovary. Vagina sublateral in position, opening posterior to cirrus sac into genital atrium; vaginal sphincter absent. Genital pores lateral, irregularly alternating, $58-77 \%(64 \pm 5 ; 13)$ of proglottid length from posterior end. Vitellarium follicular; vitelline follicles large, 9-36 $(20 \pm 7 ; 12 ; 36)$ long by $8-30(15 \pm 5 ; 12 ; 36)$ wide, in 2 columns on each lateral margin of proglottid, extending from posterior margin of proglottid to stopping short of anterior limit of testicular field, uninterrupted by ovary. Uterus saccate, extending along mid-line of proglottid from level of ovarian bridge to level of anterior limit of vitelline follicles. Excretory ducts in 2 pairs. Eggs unembryonated, shallowly dolioform, $12-16(14 \pm 1 ; 2 ; 12)$ long by $26-31(28 \pm 2 ; 2 ; 12)$ wide, arranged in tandem in cocoons; cocoons in form of continuous strand of up to hundreds of eggs (Fig. 4A,B).

Type and only host: Zanobatus schoenleinii (Müller et Henle), striped panray (Rhinopristiformes: Zanobatidae).

Type locality: Atlantic Ocean, off Soumbedioune $\left(14^{\circ} 40^{\prime} \mathrm{N} ; 17^{\circ} 27^{\prime} \mathrm{W}\right)$, Senegal, Africa.

Additional localities: Atlantic Ocean, off Kafountine $\left(12^{\circ} 55^{\prime} \mathrm{N} ; 16^{\circ} 45^{\prime} \mathrm{W}\right)$, Casamance, and off Joal $\left(14^{\circ} 10^{\prime} \mathrm{N}\right.$; $\left.16^{\circ} 51^{\prime} \mathrm{W}\right)$, Mbour $\left(14^{\circ} 42^{\prime} \mathrm{N} ; 16^{\circ} 59^{\prime} \mathrm{W}\right)$ and Ouakam $\left(14^{\circ} 43^{\prime} \mathrm{N} ; 17^{\circ} 29^{\prime} \mathrm{W}\right)$, Senegal, Africa.

Site of infection: Spiral intestine.

Prevalence of infection: $82 \%$ (18 of 22 host specimens).

Specimens deposited: MNHN HEL428 (holotype) and MNHN HEL429-432 (4 paratype: 2 mature worms, 1 mature and 1 gravid detached proglottid); IPCAS C-666 (1 paratype: mature worm); LRP 8494-8502 (9 paratypes: 6 mature worms [1 without scolex], 3 mature detached proglottids, and 1 lactophenol preparation of eggs); USNM 1251620-1251628 (9 paratypes: 5 mature worms, 1 mature and 1 gravid detached proglottid, and 1 lactophenol preparation of eggs). Four whole worms prepared for SEM retained in the collection of $\mathrm{KJ}$ at the University of Kansas.

E t y m o log y: The specific epithet, minor (lesser in Latin) refers to the fact that this is the smaller of the two members of the genus parasitising $Z$. schoenleinii.

\section{Zanobatocestus major sp. $\mathrm{n}$.}

Figs. 1D-F, 3, 4C

Description (based on 7 whole mounts -5 mature, 1 immature and 1 incomplete specimens, 6 detached proglottids, proglottid cross-sections -4 posterior proglottids, scolex prepared for SEM of 1 specimen, and lactophenol preparations of 2 gravid proglottids). Mature worms 2456-3307 (2872 \pm 343 ; 5) long, maximum width at 

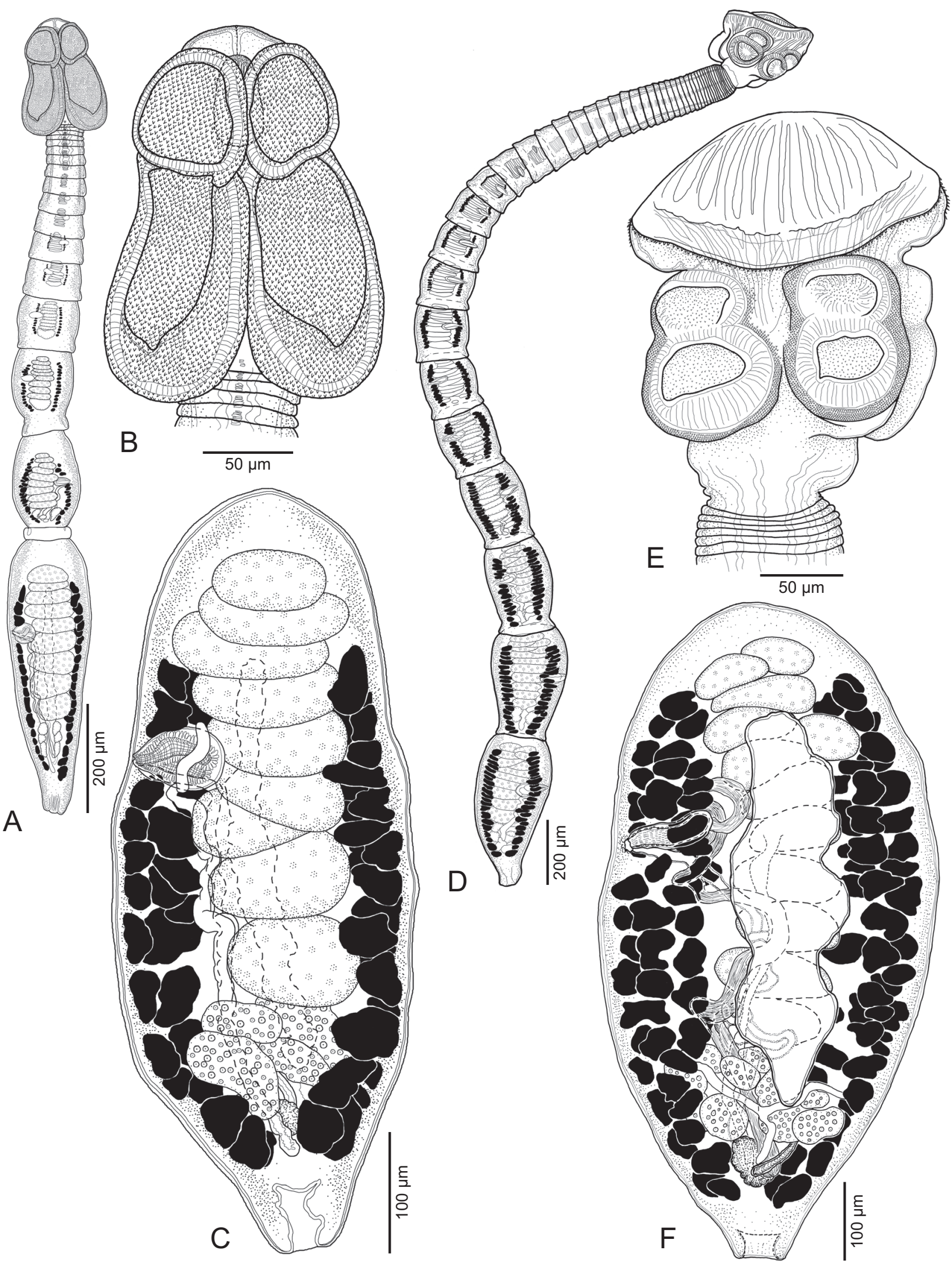

Fig. 1. A-C - Line drawings of Zanobatocestus minor gen. n. et sp. n. from Zanobatus schoenleinii. A - whole worm (holotype, MNHN HEL428); B - scolex (holotype, MNHN HEL428); C - detached mature proglottid, dorsal view (paratype, USNM 1251627). D-F - Line drawings of Zanobatocestus major gen. n. et sp. n. from Z. schoenleinii; D - whole worm (holotype, MNHN HEL425); E - scolex (paratype, USNM 1251614); F - detached mature proglottid, ventral view (paratype, USNM 1251616). 

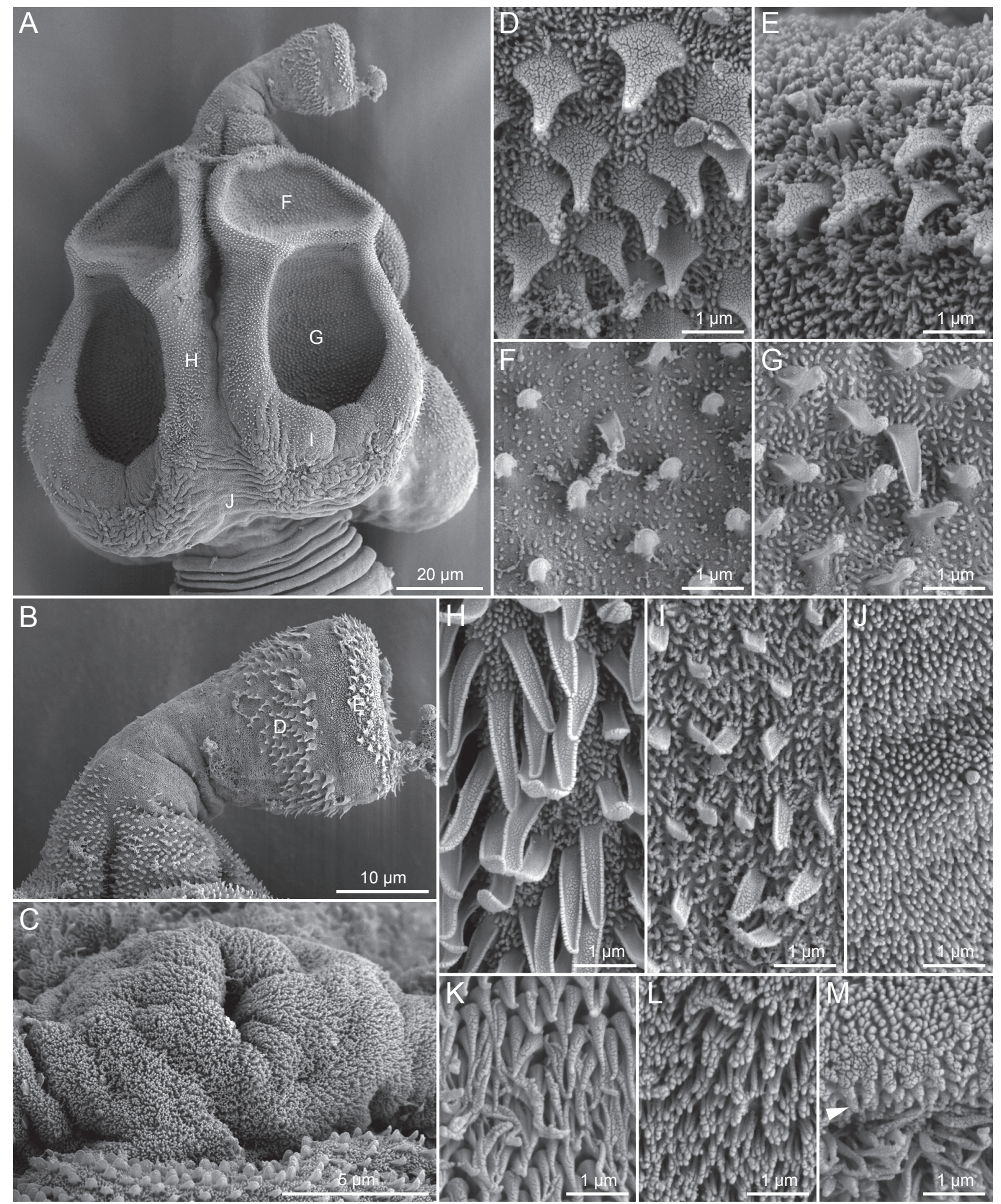

Fig. 2. Scanning electron micrographs of Zanobatocestus minor gen. n. et sp. n. from Zanobatus schoenleinii. A - scolex with everted apical modification of scolex proper (AMSP); small letters indicate location of details shown in Fig. 2F-J; B - AMSP; small letters indicate location of details shown in Fig. 2D,E; C - apex of scolex with invaginated AMSP; D - posterior band of hastate spinitriches and acicular filitriches on AMSP; $\mathbf{E}$ - anterior band of hastate spinitriches and capilliform filitriches on AMSP; F - sparse, short gladiate spinitriches and papilliform to acicular filitriches on distal bothridial surface of anterior loculus; $\mathbf{G}$ - sparse, short gladiate spinitriches and acicular filitriches on distal bothridial surface of posterior loculus; $\mathbf{H}$ - denser and longer gladiate spinitriches and acicular to capilliform filitriches on lateral proximal bothridial surface; I - sparse and short gladiate spinitriches and acicular to capilliform filitriches on posterior proximal bothridial surface; $\mathbf{J}$ - capilliform filitriches on scolex proper; $\mathbf{K}$ - small coniform spinitriches on anterior region of proglottid; $\mathbf{L}$ - capilliform filitriches on proglottid; $\mathbf{M}$ - short scolopate spinitriches (indicated by arrowhead) along posterior proglottid margin. 

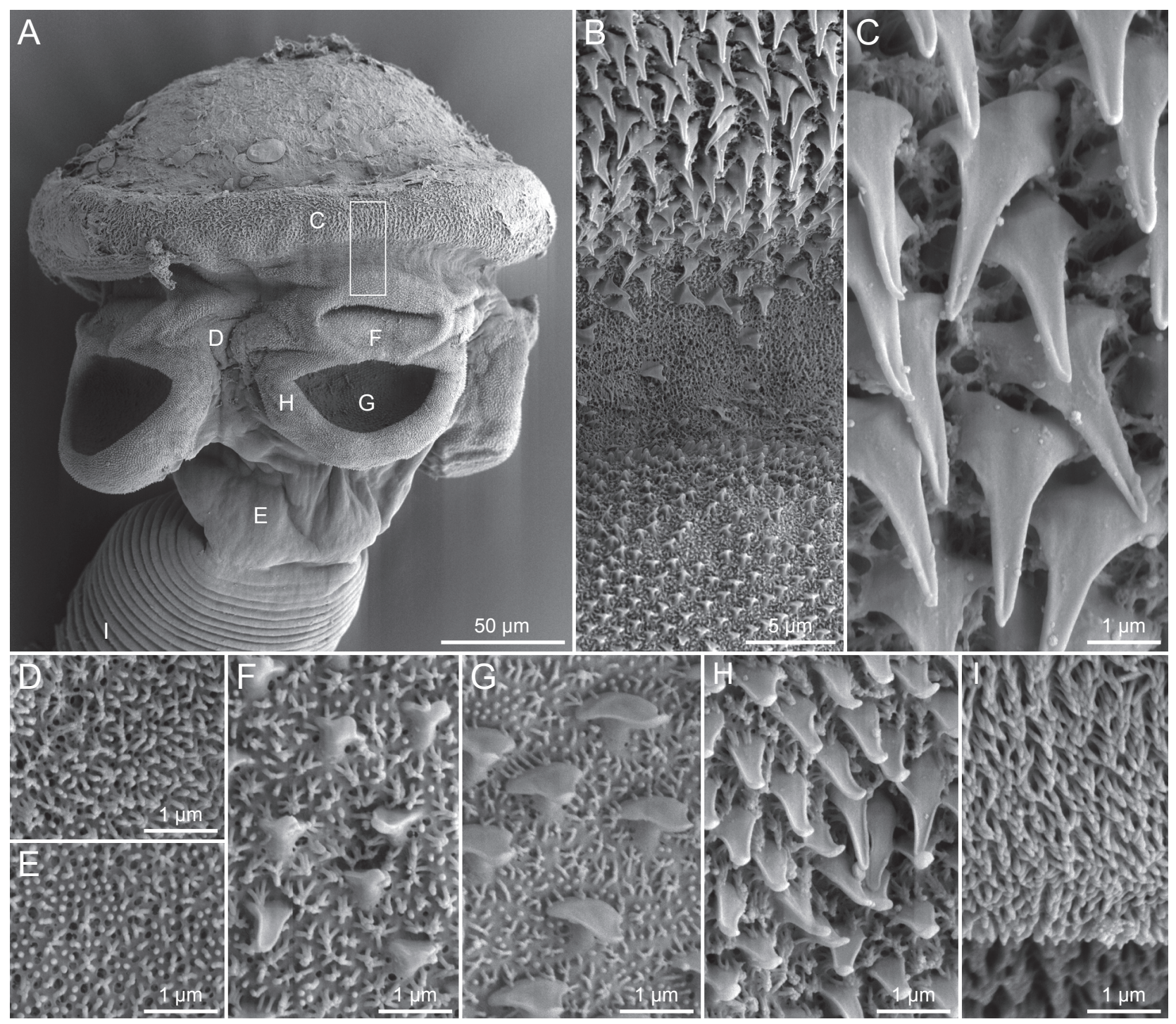

Fig. 3. Scanning electron micrographs of Zanobatocestus major gen. n., sp. n. from Zanobatus schoenleinii. A - scolex; small letters indicate location of details shown in Fig. 3C-I; box outlines location of details shown in Fig. 3B; $\mathbf{B}$ - microthrix transition from proximal bothridial surface to apical modification of scolex proper (AMSP); $\mathbf{C}$ - hastate spinitriches and acicular to capilliform filitriches on AMSP; D - acicular to capilliform filitriches on scolex proper between bothridia; $\mathbf{E}$ - acicular to capilliform filitriches on scolex proper posterior to bothridia; $\mathbf{F}$ - sparse gladiate spinitriches and acicular filitriches on distal bothridial surface of anterior loculus; $\mathbf{G}$ - sparse gladiate spinitriches and acicular filitriches on distal bothridial surface of posterior loculus; $\mathbf{H}$ - denser gladiate spinitriches and acicular to capilliform filitriches on proximal bothridial surface; I - capilliform filitriches on proglottid, slightly decreasing in length towards posterior proglottid margin.

level of apical modification of scolex proper, euapolytic; proglottids 38-52 (44 $\pm 5 ; 5)$ in number. Scolex 174-274 $(225 \pm 40 ; 7)$ long by $185-268(219 \pm 26 ; 7)$ wide, consisting of four acetabula, apical modification of scolex proper and apical organ. Acetabula bothridiate in form, $123-173(142 \pm 18 ; 5 ; 10)$ long by $97-120(110 \pm 8 ; 7$; 14) wide, biloculated. Anterior loculus shallowly elliptoid, 49-67 (57 \pm 7 ; 5; 10) long by 75-92 (81 $\pm 5 ; 5$; 9) wide; posterior loculus broadly elliptoid to obdeltoid, 71-110 $(89 \pm 12 ; 6 ; 12)$ long by $86-113(101 \pm 7 ; 7 ; 14)$ wide; ratio of anterior loculus length to posterior loculus length $0.57-0.73: 1(0.66: 1 \pm 0.06 ; 5 ; 10)$. Apical modifica- tion of scolex proper in form of conspicuous rim, noninvaginable, with extensive aperture at center, housing apical organ. Apical organ extensive, with external surface, retractable, primarily glandular, in form of shallowly elliptoid pad, 108-128 (114 \pm 9 ; 4) long by 236-303 $(282 \pm 31 ; 4)$ wide when fully everted.

Scolex proper between and posterior to bothridia covered with acicular to capilliform filitriches (Fig. 3D). Apical modification of scolex proper covered with hastate spinitriches and acicular to capilliform filitriches (Fig. 3B,C). Distal bothridial surfaces covered with sparse gladiate spinitriches and acicular filitriches 

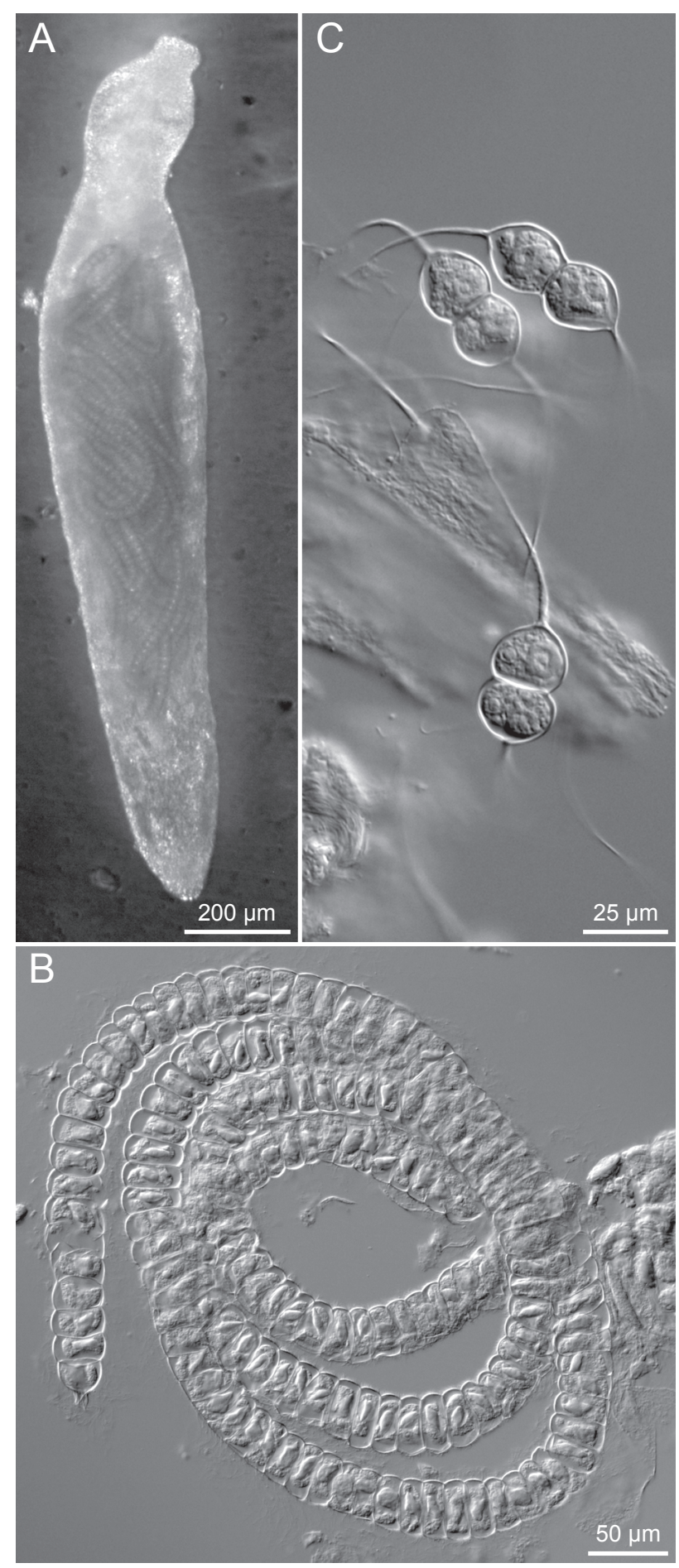

Fig. 4. Photomicrographs of cocoons of Zanobatocestus minor gen. n. et sp. n. and Z. major gen. n. et sp. n. from Zanobatus schoenleinii. A - detached gravid proglottid of Z. minor showing uterus filled with strand-like cocoon; $\mathbf{B}$ - cocoon of $Z$. minor in form of linear strand; $\mathbf{C}$ - cocoons of $Z$. major showing doublets of eggs with bipolar filaments.

(Fig. 3F,G). Proximal bothridial surfaces covered with denser gladiate spinitriches and acicular to capilliform filitriches (Fig. 3B,H). Proglottids covered with capilliform filitriches throughout, slightly decreasing in length along posterior proglottid margin (Fig. 3I).

Cephalic peduncle absent. Proglottids craspedote, non-laciniate. Immature proglottids $37-51(42 \pm 5 ; 6)$ in number, initially wider than long, becoming longer than wide with maturity; posteriormost immature proglottid $266-330(303 \pm 24 ; 5)$ long by $175-233(208 \pm 25 ; 5)$ wide. Mature proglottids $1-2$ in number; terminal mature proglottid $365-543(457 \pm 75 ; 5)$ long by $204-276$ $(233 \pm 30 ; 5)$ wide; detached mature proglottids 797-934 $(868 \pm 61 ; 4)$ long by $222-464(373 \pm 105 ; 4)$ wide. Testes $10-13(12 \pm 1 ; 12 ; 14)$ in number, $12-60(33 \pm 15$; 7 ; $21)$ long by $37-107(71 \pm 19 ; 7 ; 21)$ wide, in 1 irregular column anterior to ovary. Vas deferens weakly looping, extending sublaterally from level of ootype region to anterior margin of cirrus sac, not expanded to form external seminal vesicle. Internal seminal vesicle not observed. Cirrus sac pyriform, $61-98(78 \pm 14 ; 7)$ long by $16-52$ $(31 \pm 12 ; 7)$ wide, containing coiled cirrus. Cirrus likely unarmed.

Ovary lobate, $\mathrm{H}$-shaped in frontal view, tetralobed in cross-section, 32-92 $(56 \pm 21 ; 6)$ long by 64-93 (79 \pm 11 ; 5 ) wide. Mehlis' gland posterior to ovary. Vagina sublateral in position, looping, opening posterior to cirrus sac into genital atrium. Genital pores lateral, irregularly alternating, 55-69\% $(63 \pm 5 ; 7)$ of proglottid length from posterior end. Vitellarium follicular; vitelline follicles relatively large, $11-31(18 \pm 7 ; 6 ; 18)$ long by $12-50(32 \pm 12 ; 6 ; 18)$ wide, in $2-3$ columns on each lateral margin of proglottid, extending from posterior margin of proglottid to anterior margin of testicular field, uninterrupted by ovary. Uterus saccate, extending along mid-line of proglottid from level of ovarian bridge to level of anterior limit of vitelline follicles. Excretory ducts in 2 pairs. Eggs unembryonated, broadly to very broadly ovoid, arranged in cocoons of doublets (2 eggs), very rarely singlets ( 1 egg) or triplets (3 eggs); cocoons $34-41(38 \pm 2 ; 2 ; 13)$ long by $21-24$ $(22 \pm 1 ; 2 ; 13)$ wide, with bipolar filaments (Fig. 4C); filaments $65-182(125 \pm 38 ; 2 ; 13)$ long.

Type and only host: Zanobatus schoenleinii (Müller et Henle), striped panray (Rhinopristiformes: Zanobatidae).

Type locality: Atlantic Ocean, off Soumbedioune $\left(14^{\circ} 40^{\prime} \mathrm{N} ; 17^{\circ} 27^{\prime} \mathrm{W}\right)$, Senegal, Africa.

Additional localities: Atlantic Ocean, off Mbour $\left(14^{\circ} 42^{\prime} \mathrm{N} ; 6^{\circ} 59^{\prime} \mathrm{W}\right)$, Senegal, Africa.

Site of infection: Spiral intestine.

Prevalence of infection: $18 \%$ (4 of 22 host specimens).

Specimens deposited: MNHN HEL425 (holotype) and MNHN HEL426, 427 (2 paratypes: 1 mature worm and 1 mature detached proglottid); IPCAS C-665 (1 paratype: 1 mature worm); LRP 8486-8493 (6 paratypes: 1 mature and 1 incomplete worm, 1 mature and 1 gravid detached proglottid, 1 proglottid cross-section series with strobilar voucher, and 1 lactophenol preparation of eggs); USNM 1251614-1251619 (6 paratypes: 1 mature and 1 immature worm, 2 mature and 
1 gravid detached proglottid, and 1 lactophenol preparation of eggs). One scolex (same specimens as used for proglottid cross-sections) prepared for SEM retained in the collection of KJ at the University of Kansas.

Etymology: The specific epithet, major (greater in Latin) refers to the fact that this is the larger of the two members of the genus parasitising $Z$. schoenleinii.

Remarks. As its name suggests, Z. major sp. n. differs from its only congener, $Z$. minus, in the overall size of mature worms; it is larger in total length $(2456-3307 \mu \mathrm{m}$ vs 963-1635 $\mu \mathrm{m}$ ), has a conspicuously greater number of proglottids (37-52 vs 15-22), and a slightly wider scolex (185-268 $\mu \mathrm{m} v s$ 113-170 $\mu \mathrm{m})$ than $Z$. minus. It also has a slightly greater number of testes (10-13 vs 8-10) and vitelline follicles that extend farther anterior than they do in Z. minus. Most conspicuously, this new species bears an apical modification of the scolex proper that is wide and short, and an apical organ that is extensive and primarily external, rather than an apical modification of the scolex proper that is narrow and elongated, and an apical organ that is small and internal as in Z. minor. Moreover, the eggs of $Z$. major are arranged in doublets (rarely singlets or triplets) in cocoons with bipolar filaments, while those of $Z$. minor are arranged in tandem in large number in strand-like cocoons, lacking bipolar filaments. The two species further differ in scolex microthrix pattern. The gladiate spinitriches on the distal and proximal bothridial surfaces of both loculi are generally wider in Z. major than in $Z$. minor. In addition, the hastate spinitriches of the apical modification of the scolex proper are approximately 3 times longer in the former than in the latter species.

Zanobatocestus major was found to parasitise 4 of 22 specimens of $Z$. schoenleinii off Senegal; it co-occurred with $Z$. minus in 3 of these 4 host specimens.

\section{DISCUSSION}

As noted above, the most remarkable feature of the new genus is the fact that, unlike those of all 21 other lecanicephalidean genera, its bothridia are biloculated. As a consequence, based on scolex morphology, its affinities relative to other apical organ-bearing genera of the order are unclear. In proglottid anatomy, the new genus most closely resembles Anteropora Subhapradha, 1955, Polypocephalus Braun, 1878, Rexapex Koch, Jensen et Caira, 2012 and Sesquipedalapex Jensen, Nikolov et Caira, 2011. In all cases, the testes are arranged in a single column and layer and the vitelline follicles are in 2-3 lateral columns on each side of the proglottid, stopping short of the anterior margin of the proglottid. Investigation of its affinities using molecular data is likely to be informative, particularly if explored in the context of lecanicephalidean relationships overall.

The packaging of the eggs in both species of Zanobatocestus is also unusual among lecanicephalideans, at least relative to the limited number of taxa for which gravid proglottids have been examined. Unlike the single eggs seen in species of Anteropora, Polypocephalus, Sesquipedalapex and Tetragonocephalum Shipley et Hornell, 1905 (see Jensen 2005, Jensen et al. 2011), the eggs of species of Zanobatocestus are packaged in cocoons. In this respect they resemble those of Eniochobothrium Shipley et Hornell, 1906 and Paraberrapex Jensen, 2001. However, differences exist with respect to both genera as described by Jensen $(2001,2005)$, and also between the two congeners. The cocoons of Eniochobothrium euaxos Jensen, 2005 are round and contain 40-51 eggs; those of Paraberrapex manifestus Jensen, 2001 are elongate and contain 69-111 eggs arranged in several parallel tandem series. In contrast, the cocoons of Z. minus consist of a continuous strand of potentially up to hundreds of eggs, and those of $Z$. major contain only two (rarely one or three eggs) and bear thin, bipolar filaments. Bipolar filaments are also seen in the eggs of three species of Anteropora (see Jensen 2005, Jensen et al. 2011) and Polypocephalus helmuti Jensen, 2005 (see Jensen 2005), but unlike the thin, filamentous extensions of $Z$. major, those of the former genera are broader and more band-like. Nonetheless, the presence of bipolar filaments may signify similarities in first intermediate host use (e.g. consumption of eggs by a certain type of copepod) and/or transmission mechanism among these taxa.

The host associations of the new genus are also intriguing in the context of those of other lecanicephalidean genera. This is largely because Zanobatus schoenleinii is itself an idiosyncratic taxon. In addition to being the only member of its family, its affinities among batoids are uncertain. For example, most recently, based on a combination of data from morphology and molecules, Aschliman et al. $(2012 \mathrm{a}, \mathrm{b})$ found Zanobatus to group as sister to the stingrays, in the former case with two groups of guitarfish as sister groups to that larger clade and in the latter case with the thornback genera Platyrhina Müller et Henle and Platyrhinoidis Garman as sister to that larger clade. In contrast, in the more expanded molecular analyses of Naylor et al. (2012a) it grouped within the Rhinopristiformes among the families of guitarfish. With no obvious close relatives, there is no clear suite of hosts that might be explored for additional members of the genus at this time. If Zanobatocestus is restricted to this single genus and Zanobatus is confirmed to be monotypic, it is likely that Zanobatocestus will remain ditypic. Alternatively, once the affinities of Zanobatus are more completely understood, its closely related genera will serve as candidate hosts and would bear investigation. Regardless, it seems likely that this genus will remain relatively low in diversity. At present, the geographic distribution of Zanobatocestus is also extremely limited. It, like its host, occurs only in the tropical eastern Atlantic off Africa. 
Acknowledgements. This project was supported by NSF-BS\&I 0103640 to J.N. Caira, K. Jensen, P.R. Last, J.D. Stevens, G.J. P. Naylor, NSF BS\&I 0542846 and 0542941 to J.N. Caira, K.
Jensen, P.R. Last, G.J.P. Naylor, and NSF-PBI 0818696 and 0818823 to J.N. Caira, K. Jensen, T. Littlewood and J. Mariaux.

\section{REFERENCES}

Aschliman N.C., Cleason K.M., McEachran J.D. 2012a: Phylogeny of the Batoidea. In: J.C. Carrier, J.A. Musick and M.R. Heithaus (Eds.), The Biology of Sharks and Their Relatives. CRC Press, Taylor \& Francis Group, Boca Raton, pp. 57-95.

Aschliman N.C., Nishinda M., Miya M., Inoue J.G., Rosana K.M., NAYLOR G.J.P. 2012b: Body plan convergence in the evolution of skates and rays (Chondrichthyes: Batoidea). Mol. Phylogenet. Evol. 63: 28-42.

Caira J.N., Jensen K., Waeschenbach A., Olson P.D., LitTLEWOOD D.T.J. 2014: Orders out of chaos - molecular phylogenetics reveals the complexity of shark and stingray tapeworm relationships. Int. J. Parasitol. 44: 55-73.

Chervy L. 2009: Unified terminology for cestode microtriches: a proposal from the international workshops on cestode systematics in 2002-2008. Folia Parasitol. 56: 199-230.

Cielocha J.J., Jensen K. 2011: A revision of Hexacanalis Perrenoud, 1931 (Cestoda: Lecanicephalidea) and description of $H$. folifer $\mathrm{n}$. sp. from the zonetail butterfly ray Gymnura zonura (Bleeker) (Rajiformes: Gymnuridae). Syst. Parasitol. 79: 1-16.

Cielocha J.J., Jensen K. 2013: Stoibocephalum n. gen. (Cestoda: Lecanicephalidea) from the sharkray, Rhina ancylostoma Bloch \& Schneider (Elasmobranchii: Rhinopristiformes), from northern Australia. Zootaxa 3626: 558-568.

Cielocha J.J., Jensen K., Caira J.N. 2014: Floriparicapitus, a new genus of lecanicephalidean tapeworm (Cestoda) from sawfishes (Pristidae) and guitarfishes (Rhinobatidae) in the IndoWest Pacific. J. Parasitol. 100: 485-499.

Clopton R.E. 2004: Standard nomenclature and metrics of plane shapes for use in gregarine taxonomy. Comp. Parasitol. 71: 130-140.

COMPAGNO L.J.V. 2005: Global checklist of living chondrichthyan fishes. In: S.L. Fowler, R.D. Cavanagh, M. Camhi, G.H. Burgess, G.M. Cailliet, S.V. Fordham, C.A. Simpfendorfer and J.A. Musick (Eds.), Sharks, Rays and Chimaeras: the Status of the Chondrichthyan Fishes. IUCN, Gland, pp. 401-423.

Diatta Y., Reynaud C., CAPAPÉ C. 2013: First case of albinism recorded in striped panray Zanobatus schoenleinii (Chondrich-

Received 4 February 2014 thyes: Platyrhinidae) from the coast of Senegal (eastern tropical Atlantic). J. Ichthyol. 53: 1007-1012.

Healy C.J., Caira J.N., Jensen K., Webster B.L., Littlewood D.T.J. 2009: Proposal for a new tapeworm order, Rhinebothriidea. Int. J. Parasitol. 39: 497-511.

JENSEN K. 2001: Four new genera and five new species of lecanicephalideans (Cestoda: Lecanicephalidea) from elasmobranchs in the Gulf of California. J. Parasitol. 87: 845-861.

JENSEN K. 2005: A monograph on the Lecanicephalidea (Platyhelminthes, Cestoda). Bull. Univ. Nebr. State Mus. 18: 1-241.

Jensen K., Nikolov P., Caira J.N. 2011: A new genus and two new species of Anteroporidae (Cestoda: Lecanicephalidea) from the darkspotted numbfish, Narcine maculata (Torpediniformes: Narcinidae), off Malaysian Borneo. Folia Parasitol. 58: 95-107.

Jensen K., Russell S.L. 2014: Seussapex, a new genus of lecanicephalidean tapeworm (Platyhelminthes: Cestoda) from the stingray genus Himantura (Myliobatiformes: Myliobatidae) in the Indo-West Pacific with investigation of mode of attachment. Folia Parasitol. 61: 231-241.

Косн K.R., Jensen K., Caira J.N. 2012: Three new genera and six new species of lecanicephalideans (Cestoda) from eagle rays of the genus Aetomylaeus (Myliobatiformes: Myliobatidae) from northern Australia and Borneo. J. Parasitol. 98: 175-198.

Naylor G.J.P., Caira J.N., Jensen K., Rosana K.A.M., Straube N., Lakner C. 2012a: Elasmobranch phylogeny: a mitochondrial estimate based on 595 species. In: J.C. Carrier, J.A. Musick and M.R. Heithaus (Eds.), The Biology of Sharks and Their Relatives. CRC Press, Taylor \& Francis Group, Boca Raton, pp. 31-56.

Naylor G.J.P., Caira J.N., Jensen K., Rosana K.A.M., White W.T., LAst P.R. 2012b: A DNA sequence-based approach to the identification of shark and ray species and its implications for global elasmobranch diversity and parasitology. Bull. Am. Mus. Nat. Hist. 367: 1-262.

Nelson J.S. 2006: Fishes of the World. Fourth Edition. John Wiley \& Sons, Inc., Hoboken, NJ, i-xix, 601 pp. 